\title{
The Regulatory Provision of Strategic Planning Russian Municipalities
}

\author{
O.Ye. Devyatkina ${ }^{1, *}$ and E.N. Koroleva ${ }^{1}$ \\ *Corresponding author: lya-lya9@list.ru \\ ${ }^{1}$ Samara State University of Economics, Samara, Russia
}

\begin{abstract}
The results of the in-depth analysis of the regulatory support of the strategic planning of municipalities of the Samara region are presented at the article. Also at the article identified problem areas at the regional and municipal levels, formulated proposals for improving the regulatory legal framework in the field of strategic planning of municipal development. The received proposals for the improvement of legal regulation in this area can be addressed to other Russian municipalities.
\end{abstract}

Keywords: strategic planning, municipality, region, legal regulation.

\section{Introduction}

At the present stage of development, strategic planning has priority at all levels of management of the national economy. Today, it is not disputed that this process is important, and how much it affects the prospects for municipal development.

Like any important issue affecting the interests of a wide range of participants, strategic planning requires its own legal justification. It is legal support that determines the logic of the process, the boundaries and the direction of state influence on the relevant public relations with the help of legal norms.

\section{Problem Statement}

The Constitution of the Russian Federation and the Federal Law of 06.10.2003 N 131-Ф3 "On the General Principles of the Organization of Local Self-Government in the Russian Federation" state that local self-government bodies are endowed with autonomy and a sufficient amount of powers necessary to resolve issues of sustainable social and economic development [1].

For the first time, it is determined by law that strategic planning can be carried out at the level of municipalities in the Federal Law of 28.06.2014 No. 172-Ф3 “On Strategic Planning in the Russian Federation” (hereinafter - 172-FZ). This regulatory legal act establishes the legal basis for strategic planning in the Russian Federation, the coordination of state and municipal strategic management and budget policy, the powers of federal bodies of state power, bodies of state power of constituent entities of the Russian Federation, local governments and order their interaction with public, scientific and other organizations in the field of strategic planning [2].

However, modern studies demonstrate a fairly large range of problems in implementing strategic planning at the local level [3]. Today, the procedure for ensuring the mechanisms of public participation in the process of municipal strategic planning is also particularly difficult [4].

\section{Research Questions}

Within the framework of the study, two main tasks were set:

1. What is the basis of the legal support of the strategic planning of municipalities in the Samara region?

2. What gaps (drawbacks) exist in the regulatory framework for the strategic planning of municipalities?

\section{Purpose of the Study}

The aim of the study was to identify gaps in the regulatory and legal framework for municipal strategic planning and to formulate proposals for its improvement. The study was conducted on the example of the Samara region.

\section{Research Methods}

General scientific methods, methods of logical, comparative analysis. The main used method is formal legal method. Also general scientific methods, methods of logical, comparative analysis are used. 


\section{Findings}

Strategic planning in the Russian Federation is carried out at the federal level, the level of the constituent entities of the Russian Federation and the level of municipal formations [2]. At the level of the constituent entity of the Russian Federation, a separate regulatory legal act may be adopted. So, in the Samara region in the current year the Law of the Samara region was adopted from 12.03.2018 N 19-DG "On strategic planning in the Samara region", the terms of reference of which include the procedure for implementing strategic planning in the Samara region, areas of strategic planning [5].

The analysis of this law allows to conclude that there is a need for a number of additional legal acts at the level of a constituent entity of the Russian Federation, such as:

- The order of development, adjustment, monitoring and control of the implementation of the strategy of socioeconomic development of the Samara region (approved by the Decree of the Government of the Samara Region dated December 30, 2015 N 913 "On approval of the Procedure for the development, adjustment, implementation of monitoring and control of the implementation of the strategy of socio-economic development of the Samara Region");

- The order of development, adjustment, monitoring and control of the implementation of the forecast of socioeconomic development of the Samara region (approved by the Decree of the Government of the Samara Region of September 25, 2015 No. 604 "On Approval of the Procedure for Developing, Adjusting, Implementing Monitoring and Monitoring the Implementation of the Forecast of the Socio-Economic Development of the Samara Region for the Long-term Period");

- The order of development and approval, the period of validity, as well as the requirements for the composition and content of the budget forecast of the Samara region (approved by the Decree of the Government of the Samara Region dated February 17, 2017 N 104 "On approval of the budget forecast of the Samara Region for the long-term period until 2030");

- The order of development and adjustment of the forecast of socio-economic development of the Samara region (approved by the Decree of the Government of the Samara Region dated February 4, 2009 No. 24 "On the Approval of the Procedure for Developing a Forecast of the Socio-Economic Development of the Samara Region for the Next Fiscal Year and Planning Period");

- Action plan for the implementation of the strategy of socio-economic development of the Samara region [6];

- State programs of the Samara region (approved by the Order of the Government of the Samara Region of 04.10.2016 No. 756-p "On Approval of the List of State Programs of the Samara Region", taking into account the Order of the Government of the Samara Region of 08/31/2017 No. 761-p "On Amending the Order of the Government of Samara Region of 04.10. 2016 No. 756-p "On Approval of the List of State Programs of the Samara Region", Government Order of 17.05.2018 N 360-p "On Amendment to the Order of the Government of the Samara Region of 04.10.2016 No. 756-p" On Approval of the List of State Programs Samara region " [7]);

- Territorial planning scheme of the Samara region (approved by the Decree of the Government of the Samara Region of December 13, 2007 No. 261 "On Approval of the Scheme of Territorial Planning of the Samara Region”);

- Form, procedure and terms of public discussion of the draft strategic planning document of the Samara Region;

- The procedure for monitoring and controlling the implementation of strategic planning documents of the Samara Region.

The development of all the listed documents is entrusted to the Government of the Samara Region.

For the municipal level, strategic planning is defined as an activity on goal-setting, forecasting, planning and programming the socio-economic development of municipalities, aimed at solving the tasks of sustainable socioeconomic development of municipalities [2]. The rules of 172-FZ apply to all types of municipalities.

The powers of local governments in the field of strategic planning include [2]:

1) determination of long-term goals and objectives of municipal management and socio-economic development of municipalities, consistent with the priorities and objectives of the socio-economic development of the Russian Federation and subjects of the Russian Federation;

2) development, consideration, approval (approval) and implementation of strategic planning documents on issues falling under the authority of local governments;

3) monitoring and control of the implementation of strategic planning documents approved (approved) by local authorities;

4) other powers in the field of strategic planning, defined by federal laws and municipal regulatory legal acts.

172-FZ establishes that the procedure for developing a strategy for the socio-economic development of a municipality and an action plan for implementing a strategy for the socio-economic development of a municipality is determined, if necessary, by each municipality independently. There are no unified methodological recommendations for developing strategies for the socio-economic development of the municipality and action plans for implementing the strategy for the socio-economic development of the municipality.

The budget forecast of the municipality for the long-term period and the order of development and approval, the period of validity, as well as the requirements for the composition and content of the budget forecast of the municipality for the long-term period are developed and established by the local administration in compliance with the requirements of the Budget Code and the Methodological Recommendations for the preparation and execution of the budgets of the subjects of the Russian Federation and local budgets on the basis of state (municipal) programs (Letter of the Ministry of Finance of Russia dated September 30, 2014№ 09-05-05/4884) [8]. 
Municipal programs are approved by the local administration of the municipality (Budget Code, Article 179). Procedures for the development, implementation and evaluation of the effectiveness of municipal programs and guidelines for the development of municipal programs of individual constituent entities of the Russian Federation are established by the municipal legal act of the local administration of the municipal entity.

There is also a fairly large group of documents of municipalities not regulated by 172-FZ, including documents on the territorial planning of municipalities (territorial planning schemes of municipal districts; master plans for settlements; master plans for urban districts). The composition, the procedure for preparing the territorial planning documents of municipalities, the procedure for preparing changes and introducing them into such documents, as well as the composition and the procedure for preparing implementation plans for such documents are established in accordance with the Town Planning Code, laws and other regulatory legal acts of constituent entities of the Russian Federation, regulatory legal acts of the authorities local government (Town Planning Code, Article 18). Guidelines for the development of draft master plans for settlements and urban districts approved by the Order of the Ministry of Regional Development of Russia on May 26, 2011 № 244 [9].

Considering the regulatory and legal framework developed in the Samara region in this area, it can be stated that the majority of regulatory acts provided by the federal legislator are in the Samara region. In addition, many municipalities have already formed or are forming documents regulating strategic planning in their territories. Nevertheless, in the field of strategic planning of municipal development, many problem areas remain.

1) The absence in the Samara region of the Action Plan for the implementation of the strategy of socio-economic development of the Samara region. Nevertheless, on the official website of the Ministry of Economic Development and Investments of the Samara Region on July 9, 2017, a draft Action Plan for the implementation of Phase I (2018 - 2020) of the Strategy for the Socio-Economic Development of the Samara Region for the period up to 2030 and the announcement of Invitation to discuss the draft Action Plan for the implementation of Phase I (2018 - 2020) of the Strategy for Social and Economic Development of the Samara Region for the Period until 2030 The strategy of socioeconomic development of the Samara region for the period up to 2030 [6, 10]. This fact is based on Article 11 of the Law of the Samara Region of 12.03.2018 No. 19-DG "On Strategic Planning in the Samara Region" (adopted by the Samara Provincial Duma on 27.02.2018), according to which drafts of strategic planning documents of the Samara region are submitted for public discussion taking into account the requirements of the legislation of the Russian Federation, including legislation of the Russian Federation on state, commercial, official and other secrets protected by law [5]. Thus, there is every reason to expect that this gap in the regulatory framework for the strategic planning of municipalities in the Samara Region will be eliminated in the very near future.

2) The absence at the level of the Samara Oblast of a regulatory legal act regulating the form, procedure and terms of public discussion of the draft strategic planning document. At the same time, a number of municipal districts are ahead of the constituent entity of the Russian Federation and have relevant documents developed and adopted, for example, the municipal district Stavropol (Resolution of the Administration of the municipal district Stavropol of the Samara region dated December 29, 2016 N 341 "On approval of the procedure for public discussion of draft documents of strategic planning of the municipal district Stavropol of the Samara region"), City District Kinel (Resolution of the Administration of the City District of Kinel of the Samara Region dated 03.10.2016 N 3003 "On Approval of the Procedure for Public Discussion of the Draft Strategic Planning Documents of the City District of Kinel of the Samara Region") and so on.

3) The need to adopt a procedure for monitoring and controlling the implementation of strategic planning documents for the Samara region. Currently, the Samara Region has an Order of development, adjustment, monitoring and control of the implementation of the forecast of socio-economic development of the Samara Region for a long-term period, approved by the Government of the Samara Region dated September 25, 2015 N 604.

4) The lack of regulatory documents approved at the level of the Samara Region, which provide for methodological unity and coherence of the socio-economic development strategies of urban districts and municipal districts with the Socio-Economic Development Strategy of the Samara Region until 2030.

5) A separate direction in this problem is the question of the development of a local regulatory framework. To become the real basis of the strategic planning and management system, it must be developed and adjusted for the whole range of relevant works and in relation to the existing legal basis of regional and federal levels. The main procedures for organizing the regulatory support of strategic planning of municipalities should be: correction of the Charter of the municipality in accordance with the strategic documents; regulatory consolidation of strategic functions for administrative units; regulatory and legal consolidation of financial and economic relations in relation to the implementation of the strategy.

\section{Conclusion}

The foregoing implies the need for a systematic elaboration of the regulatory framework for strategic planning at the level of municipalities in the Russian Federation. Eliminating the gaps identified in this study using the example of municipalities of the Samara region will improve the effectiveness of strategic planning, while increasing the content of documents will expand the possibilities of using it in practice for making decisions. The findings and proposals for improving the legal regulation in this area can be addressed to other Russian municipalities. 


\section{References}

1. Federal'nyj zakon "Ob obshih printsjpah mestnogo samoupravlenija v Rossijskoj Federatsii" ot 06/10/2003 N 131-FZ. Retrieved from: http://www.consultant.ru/document/cons doc_LAW 44571/ Accessed: 29.12.2018 (2003). [in Rus.].

2. Federal'nyj zakon "O strategicheskom planirovanii v Rossijskoj Federatsii" ot 28.06.2014 N 172-FZ. Retrieved from: http://www.consultant.ru/document/cons_doc_LAW_164841/ Accessed: 29.12.2018 (2014). [in Rus.].

3. B.S. Zhiharevich, T.K. Pribishin, Municipal strategic planning in Russia between crises. News of the Russian Geographical Society, 3, 1-13 (2016).

4. E.N. Koroleva, M.V. Kurnikova, Work with the population in local government: training manual for the program of advanced training courses. Samara: Samara State University of Economics (2018).

5. Zakon Samarskoy oblasti "O strategicheskom planirovanii v Samarskoj oblasti" ot 12.03.2018 N 19-DG. Retrieved from: http://economy.samregion.ru/ Accessed: 29.12.2018 (2018). [in Rus.].

6. Proekt plana meroprijatij I etapa (2018-2020) Strategii socialno-economicheskogo razvitija Samarskoj oblasti na period do 2030 goda. Retrieved from: http://economy.samregion.ru/programmy/strategy_programm/proekt_strateg/ Accessed: 29.12.2018 (2018). [in Rus.].

7. Perechen gosudarstvennjh program Samarskoj oblasti. Retrieved from: http://economy.samregion.ru/programmy/gpso/perechen-gosudarstvennykh-programm/ $\quad$ Accessed: 29.12 .2018 (2018). [in Rus.].

8. A.V. Klimenko, V.A. Korolev, D.U. Dvinskih, N.A. Richkova, I.U. Slastihina, Strategic planning in the Russian Federation: State of methodological support, 8. Retrieved from: https://publications.hse.ru/preprints/194820163 Accessed: 09.10.2018 (2016). [in Rus].

9. Prikaz Ministerstva regionalnogo razvitija Rossijskoj Federatsii “Ob utverzhdeii Metodicheskih rekomendatsjj po razrabotke proektov generalnjh planov poselenij I gorodskih okrugov” ot 26.05.2011 N 244. Retrieved from: http://economy.gov.ru/minec/about/structure/depstrateg/2015051413. Accessed: 29.12.2018 (2011). [in Rus.].

10. Postanovlenie Pravitelstva Samarskoj oblasti “Ob utverghdenii strategii sotsjalno-economicheskoga razvitiya Samarskoj oblasti” ot $12.07 .2017 \quad$ N $441 . \quad$ Retrieved from: http://economy.samregion.ru/programmy/strategy_programm. Accessed: 29.12.2018 (2017). [in Rus.]. 